Keywords: Cellulose degradation, $C D P, \mathrm{Kd}$, iodine, technetium, performance assessment, dissolved organic carbon

Retention: Permanent

\title{
Revised Guidelines for using Cellulose Degradation Product- Impacted Kd Values for Performance Assessments and Composite Analyses
}

Daniel I. Kaplan

May 2012

Savannah River National Laboratory Savannah River Nuclear Solutions, LLC Aiken, SC 29808

Prepared for the U.S. Department of Energy under

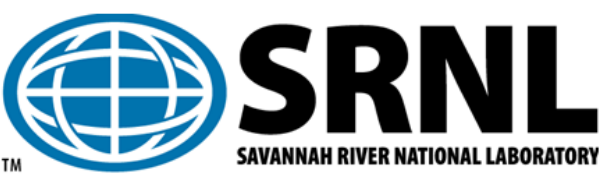
contract number DE-AC09-08SR22470. 
SRNL-STI-2012-00138

Revision 0

\section{DISCLAIMER}

This work was prepared under an agreement with and funded by the U.S. Government. Neither the U.S. Government or its employees, nor any of its contractors, subcontractors or their employees, makes any express or implied:

1. warranty or assumes any legal liability for the accuracy, completeness, or for the use or results of such use of any information, product, or process disclosed; or

2. representation that such use or results of such use would not infringe privately owned rights; or

3. endorsement or recommendation of any specifically identified commercial product, process, or service.

Any views and opinions of authors expressed in this work do not necessarily state or reflect those of the United States Government, or its contractors, or subcontractors.

\section{Printed in the United States of America \\ Prepared for \\ U.S. Department of Energy}




\section{REVIEWS AND APPROVALS}

AUTHOR:

Daniel I. Kaplan, Environmental Sciences

Date

TECHNICAL REVIEWER:

Morgana T. Whiteside, Environmental Sciences

Date

APPROVERS:

David A. Crowley, Manager, Radiological Performance Assessment

Date

Jack Mayer, Manager, Environmental Sciences

Date

Robert S. Aylward, Manager, Environmental Restoration Technology

Date 


\section{EXECUTIVE SUMMARY}

Cellulosic materials include wood, paper, rags, and cardboard products. These materials are co-disposed with radiological waste at the Savannah River Site's (SRS) E-Area Low-Level Waste Facility (ELLWF). Cellulosic materials readily degrade in the environment to form cellulose degradation products (CDP) that will partition to the sediment or remain mobile in the groundwater. Savannah River National Lab (SRNL) has conducted studies to estimate the impact of CDP on radionuclide sorption to SRS sediments (Kd values). It was found that CDP impact on radionuclide sorption varies with radionuclide and CDP concentration. Furthermore, it was found that the amount of carbon (C) in the system could increase or decrease $K d$ values with respect to the base case of when no CDP was added. Throughout the expected $\mathrm{pH}$ range of the ELLWF, a low concentration of CDP in the system would increase $K d$ values (because C would sorb to the sediment and provide more exchange sites for radionuclides to sorb), whereas greater concentrations of CDP ( $\geq 20 \mathrm{mg} / \mathrm{L} \mathrm{C}$ ) would decrease $K d$ values (because C would remain in solution and complex the radionuclide and not permit the radionuclide to sorb to the sediment).

A review of $>230$ dissolved organic carbon (DOC) groundwater concentrations in the Old Radioactive Waste Burial Ground (ORWBG) at the SRS indicated that the average DOC concentration, a gross measure of CDP, was $5 \mathrm{mg} / \mathrm{L} \mathrm{C}$. At approximately this DOC concentration, the laboratory studies demonstrated that no anions (Tc, I, or Se) or cations $(\mathrm{Ni}, \mathrm{Sr}, \mathrm{Ce}, \mathrm{Eu}, \mathrm{Zr}$, or $\mathrm{Th}$ ) have decreased sorption in the presence of carbon (an analogue for CDP).

The CDP-correction factor, $f_{C D P}$, has been used to calculate a CDP-corrected $K d$ value, $K d_{C D P}$ :

$$
K d_{C D P}=f_{\mathrm{CDP}} \times K d
$$

Previously, the CDP-correction factor, $f_{C D P}$, used in the Performance Assessment (PA) was conservatively selected from a system containing $20 \mathrm{mg} / \mathrm{L} \mathrm{C}$, i.e., a system that decreased selected $K d$ values with respect to no CDP present. After reviewing the literature for this report, it is recommended that the criteria for selecting the CDP-correction factor be revised to reflect better the carbon system expected, $5 \mathrm{mg} / \mathrm{L} \mathrm{C}$. As noted above, no decrease in $K d$ values were observed in systems receiving $5 \mathrm{mg} / \mathrm{L} \mathrm{C}$. Therefore, it is recommended that the use of the $K d_{C D P}$ be discontinued and that the conventional $K d$ value be used in instances where $K d_{C D P}$ was previously used. 


\section{TABLE OF CONTENTS}

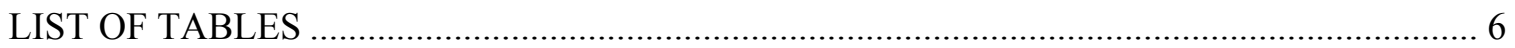

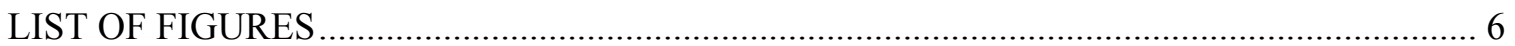

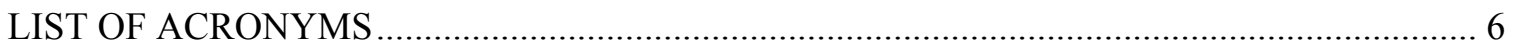

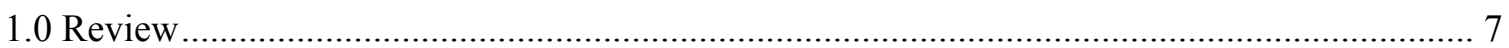

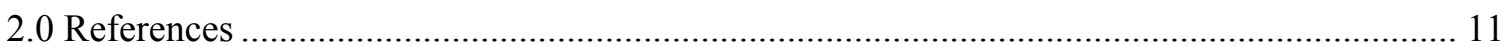

3.0 Appendix A: Experimentally Derived CDP Correction Factors and CDP-Corrected Kd Values 12

4.0 Appendix B: Total Organic Carbon Concentrations in the Old Radioactive Waste Burial

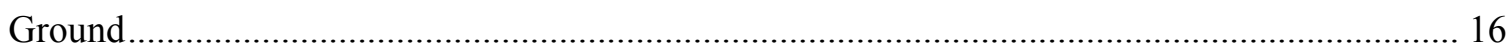




\section{LIST OF TABLES}

Table 1. Radionuclide cations: CDP Correction Factors, $f_{C D P}$, and CDP-Corrected $K d$ values, $K d_{C D P}$, (assuming no enhanced sorption due to presence of CDP).

Table 2. Radionuclide anions: CDP Correction Factors, $f_{C D P}$, and CDP-Corrected $K d$ values, $K d_{C D P}$, (assuming no enhanced sorption due to presence of CDP).................................... 15

\section{LIST OF FIGURES}

Figure 1. Eu Kd values as a function of $\mathrm{pH}$ and SR-NOM (natural organic matter) concentrations in clayey (top) and sandy (bottom) sediments (all $K d$ values $>20,000 \mathrm{~mL} / \mathrm{g}$ are greater-than values).

\section{LIST OF ACRONYMS}

$\begin{aligned} \text { C } & \text { Carbon } \\ \text { CDP } & \text { Cellulose degradation products } \\ \text { DOC } & \text { Dissolved organic carbon } \\ \text { ELLWF } & \text { E-Area Low-Level Waste Facility } \\ \text { Kd } & \text { Distribution coefficient } \\ \text { LLW } & \text { Low level radioactive waste } \\ \text { NOM } & \text { Natural organic matter } \\ \text { ORWBG } & \text { Old Radioactive Waste Burial Ground } \\ \text { SRNL } & \text { Savannah River National Laboratory } \\ \text { SRS } & \text { Savannah River Site } \\ \text { TOC } & \text { Total organic carbon }\end{aligned}$




\subsection{Review}

Cellulose degradation products (CDP) are compounds resulting from the environmental degradation of cellulosic materials, including paper, cardboard, rags, and wood. Such materials were co-disposed with low level radioactive waste at the Savannah River Site's (SRS) E-Area Low-Level Waste Facility (ELLWF). Cellulosic materials are co-disposed in the E-Area LowLevel Waste Facility (ELLWF) and they have been assumed in the performance assessments (PA) that their degradation products, CDP, will enhance the transport of most radionuclides. Concentrations of CDP have been shown to influence greatly most radionuclide $K d$ values. New information has provided a better estimate of the likely CDP concentrations in E-Area. The subject of this report is to evaluate the impact of this discovery of new CDP concentration (more specifically the concentrations of a surrogate, dissolved organic matter) on E-Area $K d$ values.

Laboratory and modeling studies were conducted to determine whether CDP would influence the tendency of radionuclides to sorb to sediments, and therefore to move away from the buried waste (Kaplan, 2010a; Kaplan, 2004, 2010c; Serkiz, 1999, 1998). From these studies, the type of sediment (clayey or sandy), $\mathrm{pH}$, organic $\mathrm{C}$ content, contact time, and order of addition were evaluated. The experimental work included monovalent $\left(\mathrm{Cs}^{+}\right)$, divalent $\left(\mathrm{Ni}^{2+}\right.$, and $\left.\mathrm{Sr}^{2+}\right)$, trivalent $\left(\mathrm{Ce}^{3+}\right.$ and $\left.\mathrm{Eu}^{3+}\right)$ and tetravalent $\left(\mathrm{Zr}^{4+}\right.$ and $\left.\mathrm{Th}^{4+}\right)$ cations and anions (iodide, perrhenate, an analog for pertechnetate, and selenate) at three $\mathrm{pH}$ values $(\mathrm{pH} 3.9,5.3$ and 6.7) and five organic $\mathrm{C}$ concentrations (0 to $222 \mathrm{mg} / \mathrm{L} \mathrm{C}$ ) (Kaplan, 2004, 2006). ${ }^{1}$ The sorption results for these specific species were then applied as analogues to provide estimates of how other radionuclides with similar chemical properties may behave.

An example of the data showing Eu sorption to clayey and sandy SRS sediment is provided in Figure 1. Figure 1 shows the $K d$ values as a function of natural organic matter (NOM) additions. Natural organic matter differs from dissolved organic carbon (DOC) in that the former does not differentiate between organic matter in the aqueous or solid phase, whereas DOC quantifies only that organic matter that is in the aqueous phase. For a given system, as NOM is increased, DOC also increases (Thurman, 1985). In only one case (Cs was it noted that an increase in NOM concentrations resulted in a systematic decrease in $K d$ values. But in all other cases, the presence of NOM resulted in either no change in $K d$, or more commonly in an increase in $K d$ values at low NOM concentrations $(\leq 95 \mathrm{mg} / \mathrm{L} \mathrm{C})$ and a decrease in $K d$ values at higher NOM concentrations (222 mg/L C; except for Cs). But as stated above, this occurred systematically for several radionuclides because the organic carbon partitioned onto the sediment surfaces and increased the sorption capacity of the sediment (which has a relatively very poor sorption capacity, a cation exchange capacity of SRS sediment is commonly between 1 and 3 meq/100 g) (see Appendix A).

Overall, the experimental data showed that the CDP generally increased the $K d$ values of cations at low CDP concentrations $<20 \mathrm{mg} / \mathrm{L}$ C. In no instances did $K d$ values decrease at these low DOC concentrations. Conversely, the experimental data showed that $K d$ values decreased at CDP concentration $\geq 20 \mathrm{mg} / \mathrm{L} \mathrm{C}$. Presumably, at low concentrations, the CDP sorbed to the sediment and provided more exchange sites for the cations to sorb to, thereby increasing $K d$

\footnotetext{
${ }^{1}$ A detailed description of the application of surface complexation speciation modeling of Eu sorption to SRS sediments in the presence of CDP as a function of $\mathrm{pH}$ is presented by Kaplan et al. 2010.
} 
values, contrary to expectations. However, at elevated CDP concentrations the sediment exchange sites became swamped and the CDP remained in the aqueous phase, where it would complex the radionuclides and not permit the radionuclides to (ad)sorb to the sediment surfaces.

CDP-Correction Factors, $f_{C D P, p H, C}$, were estimated from this work that varied as a function of type of soil, $\mathrm{pH}$, and organic carbon content:

$$
f_{C D P, p H, C}=\frac{K d_{C D P, p H, C=x}}{K d_{p H, C=0}}
$$

The numerator, $K d_{C D P, p H, C=x}$, is a measure of the radionuclide $K d$ value with a sediment at a given $\mathrm{pH}$ and organic carbon content dissolved in the solution. The denominator, $K d_{p H, C=0}$ is a measure of the radionuclide $K d$ value with the same sediment and the same $\mathrm{pH}$, but without any cellulose degradation products present in the solution (i.e., carbon $=0$ ). The CDP-correction factor, $f_{C D P}$, was used to calculate a CDP-corrected $K d$ value, $K d_{C D P}$ :

$$
K d_{C D P}=f_{C D P} \times K d
$$

For the purposes of this document, the $K d$ values used to calculate $K d_{C D P}$ were those $K d$ values identified in the SRS Geochemical Data Package (Kaplan, 2010b). The pH-appropriate $f_{C D P}$ values measured using SRS sediments adjusted to four $\mathrm{pH}$ values were taken from experimental data (Table 14 in Kaplan and Serkiz (2004) and Table 7 in Kaplan and Serkiz (2006)). Kd values and $f_{C D P}$ are reproduced in Appendix A.

Presently there are no measurements of dissolved organic carbon that would be a gross measure of the amount of CDP emanating from the E-Area Low-Level Waste Facility (ELLWF). A reasonable estimate may be obtained from the Old Radioactive Waste Burial Ground (ORWBG), operated between 1953 and 1972, which lies in close proximity to the ELLWF. The ORWBG received cellulosic waste similar in composition to that in the ELLWF. An extensive DOC sampling campaign of a system of shallow monitoring wells installed in grid pattern throughout the ORWBG was conducted between 1982 and 1985 (McIntyre, 1987). A total of $>230$ measurements of DOC (referred to as total organic carbon, TOC) were made as part of this program. The data from this study is presented in Appendix B. The average DOC concentration was $5.2 \mathrm{mg} / \mathrm{L} \mathrm{C}$, not including areas where a solvent plume was known to exist. This can be compared to the average DOC concentration in a subsurface uncontaminated aquifer in F-Area that we recently measured: $0.24 \mathrm{mg} / \mathrm{L}$ (Shigeyoshi et al., 2011). As such, the average groundwater DOC value measured under the ORWBG, that had similar types of waste, sediment moisture content, type of sediment, and waste handling practices, would provided a reasonable estimate of DOC concentrations at the ELLWF, until actual DOC measurements can be obtained from the E-Area vadose zone. (Measurements of DOC at the ELLWF are planned for FY13.) The $>230$ DOC samples provided a volume averaging that was collected close to the buried waste at the LLW Burial Sites.

As mentioned above, the impact of the presence of CDP on radionuclide sorption varies greatly depending on the concentration of CDP. CDP can enhance sorption or decrease sorption. Presently, all SRS Performance Assessments and Composite Analyses base their $K d_{C D P}$ values on the assumption that $20 \mathrm{mg} / \mathrm{L} \mathrm{C}$ are present in groundwater. This value was selected to provide a conservative scenario (for the groundwater pathway); yet even at this elevated $\mathrm{C}$ concentration, only the $K d_{C D P}$ values of trivalent cations decrease (but not the mono-, di-, or tetra-valent cations 
or anionic radionuclides). As noted above, our present best estimate of CDP concentration is closer to $5 \mathrm{mg} / \mathrm{L} \mathrm{C}$. At $<20 \mathrm{mg} / \mathrm{L} \mathrm{C}$, irrespective of the isotope, no $K d$ values decrease in the presence of CDP. More specifically, all $f_{C D P}$ values are equal to unity in Equation 1 (see Appendix A; Tables 1 and 2) and $K d_{C D P}=K d$. The $K d_{C D P}$ measured under conditions closest to our best estimate of $5 \mathrm{mg} / \mathrm{L} \mathrm{C}$ is the $10 \mathrm{mg} / \mathrm{L} \mathrm{C}$ data set. This data set indicates that all $f_{C D F}=1$, or $K d_{C D P}=K d$. Therefore, the experimental data suggests that a majority of $K d$ values in the presence of CDP are in fact greater than baseline values; it was elected not to recommend increasing these values because of the desire to be conservative in our PA calculations. Given these results, it is concluded that the Performance Assessment and Composite Analysis should select the $K d_{C D P}$ based on $10 \mathrm{mg} / \mathrm{L} \mathrm{C}$. This would result in the Performance Assessment and Composite Analysis dropping the $K d_{C D P}$ construct and replacing it with the $K d$ construct. 


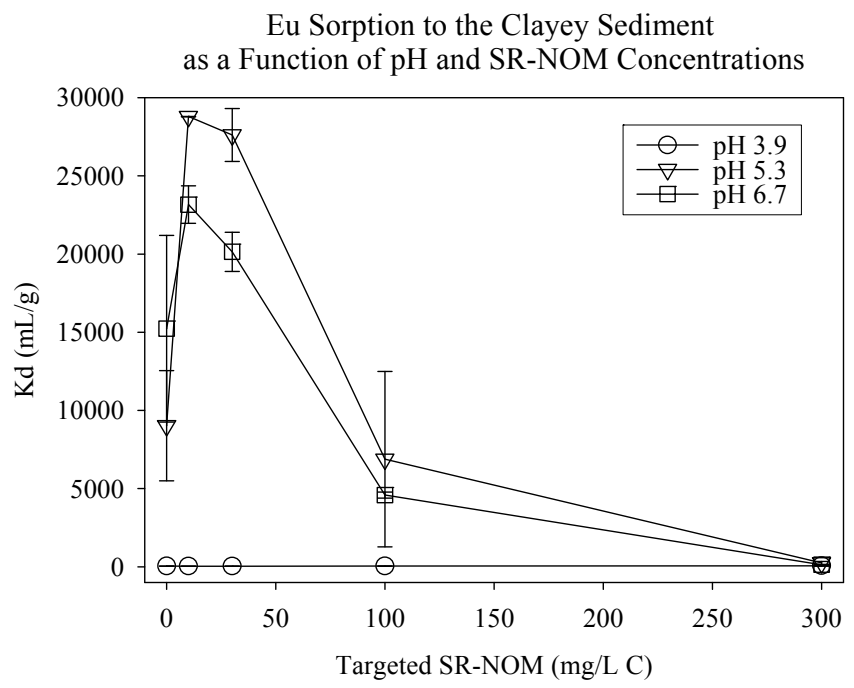

$\mathrm{Eu}$ Sorption to the Sandy Sediment as a Function of $\mathrm{pH}$ and SR-NOM Concentrations

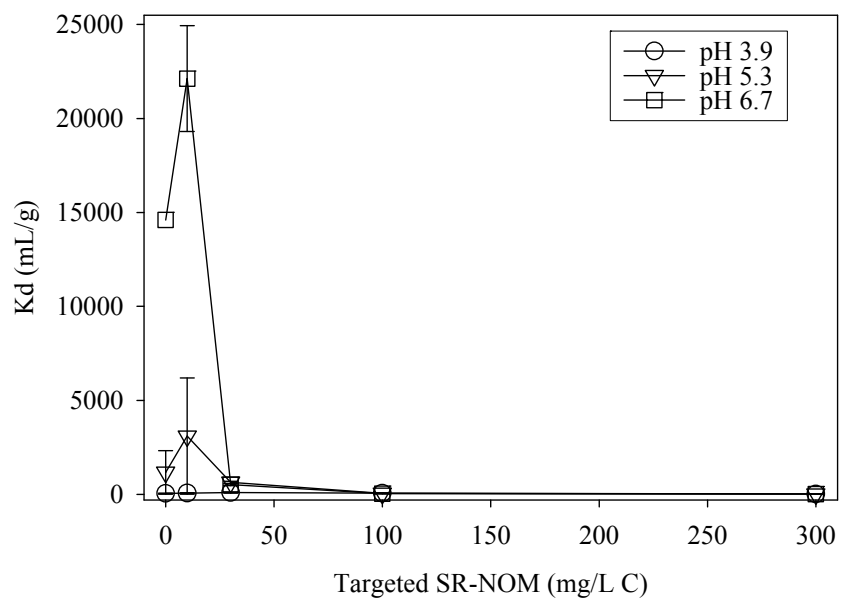

Figure 1. Eu Kd values as a function of $\mathrm{pH}$ and SR-NOM (natural organic matter) concentrations in clayey (top) and sandy (bottom) sediments (all $K d$ values assigned $K d$ values greater than $20,000 \mathrm{~mL} / \mathrm{g}$, in fact, had measured greater-than values e.g., the $K d$ value for the Sandy Sediment treated with $20 \mathrm{mg} / \mathrm{L} \mathrm{C} \mathrm{had} \mathrm{a} \mathrm{value}>22,000 \mathrm{~mL} / \mathrm{g}$ ). 


\subsection{References}

Kaplan, D. (2010a). "Geochemical data package for performance assessment calculations related to the Savannah River Site," Rep. No. SRNL-STI-2009-00473, Savannah River National Laboratory, Aiken, SC.

Kaplan, D. I. (2010b). "Geochemical Data Package for Performance Assessment Calculations Related to the Savannah River Site," Rep. No. SRNL-STI-2009-00473. Savannah River National Laboratory, Aiken, SC.

Kaplan, D. I., S. M. Serkiz (2004). "Influence of Dissolved Organic Carbon and pH on Contaminant Sorption to Sediment," Rep. No. WSRC-RP-2004-00593, Westinghouse Savannah River Company, Aiken, SC.

Kaplan, D. I., Serkiz, S. M. (2006). "Influence of Dissolved Organic Carbon and pH on Iodide, Perrhenate, and Selenate Sorption to Sediment," Rep. No. WSRC-STI-2006-00037, Washington Savannah River Company, Aiken, SC.

Kaplan, D. I., Serkiz, S. M., and J. Allison (2010c). Europium Sorption to Sediments in the Presence of Natural Organic Matter. Applied Geol. 25, 224-232.

McIntyre, P. F., Wilhite, E. L. (1987). "Effect of Organics on Radionuclide Mobility in the SRP Burial Ground.," Rep. No. DPST-87-762, Savannah River Laboratory. Aiken, SC.

Serkiz, S. M., Knaub, D., Lee, C. (1999). "Phase II Nuclide Partition Laboratory Study Influence of Cellulose Degradation Products On the Transport of Nuclides from SRS Shallow Land Burial Facilities," Rep. No. WSRC-TR-99-00298, Westinghouse Savannah River Company. Aiken, SC.

Serkiz, S. M., Knaub, D., Uhal, H. (1998). "Phase I Nuclide Partition Laboratory Study Influence of Cellulose Degradation Products On the Transport of Nuclides from SRS Shallow Land Burial Facilities," Rep. No. WSRC-TC-98-00460, Westinghouse Savannah River Company, Aiken, SC.

Shigeyoshi, O., Schwehr, K. A., Kaplan, D. I., Roberts, K. A., Zhang, S., Xu, C., Li, H.-P., Ho, Y.-F., Brinkmeyer, R., Yeager, C. M., and Santschi, P. H. (2011). Factors controlling mobility of ${ }^{127} \mathrm{I}$ and ${ }^{129} \mathrm{I}$ species in an acidic groundwater plume at the Savannah River Site. Science of the Total Environment 409, 3857-3865.

Thurman, E. M. (1985). "Organic Geochemistry of Natural Waters," Martinus Nijhoff / DR W. Junk Pulishers, Dordrecht. 
SRNL-STI-2012-00138

Revision 0

3.0 Appendix A: Experimentally Derived CDP Correction Factors and CDPCorrected KdValues 
Table 1. Radionuclide cations: CDP Correction Factors, $f_{C D P}$, and CDP-Corrected $K d$ values, $K d_{C D P}$, (assuming no enhanced sorption due to presence of CDP).

\begin{tabular}{|c|c|c|c|c|c|c|c|c|c|}
\hline \multirow[t]{2}{*}{$\begin{array}{l}\text { Radio- } \\
\text { nuclide }\end{array}$} & \multirow{2}{*}{$\begin{array}{c}\text { Present } \\
\text { sediment } \\
K d \mathrm{~s}^{(\mathrm{a})} \\
(\mathrm{mL} / \mathrm{g})\end{array}$} & \multicolumn{4}{|c|}{$\begin{array}{l}\text { CDP Correction Factors, } f_{C D P} \text {, Assuming No Enhanced } \\
\text { Sorption in the Presence of DOC }\end{array}$} & \multicolumn{4}{|c|}{ CDP Corrected $K d, K d_{C D P}(\mathrm{~mL} / \mathrm{g})$} \\
\hline & & $\begin{array}{c}10 \\
\mathrm{mg} / \mathrm{L} \mathrm{C}\end{array}$ & $\begin{array}{c}20 \\
\mathrm{mg} / \mathrm{L} \mathrm{C}\end{array}$ & $\begin{array}{c}95 \\
\mathrm{mg} / \mathrm{L} \mathrm{C}\end{array}$ & $\begin{array}{l}222 \\
\mathrm{mg} \mathrm{L} \mathrm{C}\end{array}$ & $\begin{array}{c}10 \\
\mathrm{mg} / \mathrm{L} \mathrm{C}\end{array}$ & $\begin{array}{c}20 \\
\mathrm{mg} / \mathrm{L} \mathrm{C}\end{array}$ & $\begin{array}{c}95 \\
\mathrm{mg} / \mathrm{L} \mathrm{C}\end{array}$ & $\begin{array}{c}222 \\
\mathrm{mg} / \mathrm{L} \mathrm{C}\end{array}$ \\
\hline Ac & 450 & 1.00 & 0.770 & 0.049 & 0.015 & 450 & 347 & 22 & 7 \\
\hline $\mathrm{Am}$ & 1900 & 1.00 & 0.770 & 0.049 & 0.015 & 1900 & 1464 & 94 & 29 \\
\hline$C^{(b)}$ & 2 & & & & & & & & \\
\hline $\mathrm{Cf}$ & 510 & 1.00 & 0.770 & 0.049 & 0.015 & 510 & 393 & 25 & 8 \\
\hline $\mathrm{Cm}$ & 4000 & 1.00 & 0.770 & 0.049 & 0.015 & 4000 & 3081 & 197 & 60 \\
\hline Cs & 18 & 1.00 & 1.00 & 1.00 & 1.00 & 18 & 18 & 18 & 18 \\
\hline $\mathrm{Eu}$ & 7300 & 1.00 & 0.55 & 0.04 & 0.01 & 7300 & 4006 & 306 & 94 \\
\hline $\mathrm{H}^{(\mathrm{b})}$ & 0 & & & & & & & & \\
\hline $\mathrm{I}^{(\mathrm{b})}$ & 0.6 & & & & & & & & \\
\hline $\mathrm{Nb}$ & 160 & & & & & & & & \\
\hline $\mathrm{Ni}$ & 400 & 1.00 & 1.00 & 1.00 & 0.88 & 400 & 400 & 400 & 353 \\
\hline $\mathrm{Np}$ & 5 & 1.00 & 1.00 & 1.00 & 1.00 & 5 & 5 & 5 & 5 \\
\hline $\mathrm{Pa}$ & 550 & 1.00 & 1.00 & 0.51 & 0.12 & 550 & 550 & 283 & 65 \\
\hline $\mathrm{Pb}$ & 270 & 1.00 & 1.00 & 1.00 & 0.88 & 270 & 270 & 270 & 238 \\
\hline $\mathrm{Pd}$ & 55 & 1.00 & 1.00 & 1.00 & 0.88 & 55 & 55 & 55 & 49 \\
\hline Po & 150 & 1.00 & 1.00 & 1.00 & 0.88 & 150 & 150 & 150 & 132 \\
\hline $\mathrm{Pu}$ & 370 & 1.00 & 1.00 & 0.51 & 0.12 & 370 & 370 & 190 & 44 \\
\hline $\mathrm{Ra}$ & 500 & 1.00 & 1.00 & 1.00 & 0.44 & 500 & 500 & 500 & 222 \\
\hline $\mathrm{Rb}$ & 55 & 1.00 & 1.00 & 1.00 & 1.00 & 55 & 55 & 55 & 55 \\
\hline $\mathrm{Se}$ & 36 & & & & & & & & \\
\hline $\mathrm{Sn}$ & 130 & 1.00 & 1.00 & 1.00 & 0.88 & 130 & 130 & 130 & 115 \\
\hline $\mathrm{Sr}$ & 10 & 1.00 & 1.00 & 1.00 & 0.44 & 10 & 10 & 10 & 4 \\
\hline $\mathrm{Tc}$ & 0.36 & & & & & & & & \\
\hline Th & 3200 & 1.00 & 1.00 & 0.51 & 0.12 & 3200 & 3200 & 1646 & 379 \\
\hline $\mathrm{U}$ & 800 & 1.00 & 1.00 & 1.00 & 0.44 & 800 & 800 & 800 & 356 \\
\hline $\mathrm{Zr}$ & 600 & 1.00 & 1.00 & 0.08 & 0.02 & 600 & 600 & 45 & 10 \\
\hline
\end{tabular}

\footnotetext{
${ }^{\text {(a) }}$ References for most recent Sediment Kd values are presented in (Kaplan, 2010aKaplan, 2010a)
}

(b) No analogues were included in this study for C, H, I, Se, and Tc. 
Table 2. Radionuclide anions: CDP Correction Factors, $f_{C D P}$, and CDP-Corrected $K d$ values, $K d_{C D P}$, (assuming no enhanced sorption due to presence of CDP).

\begin{tabular}{|c|c|c|c|c|c|c|c|c|c|}
\hline \multirow[t]{2}{*}{$\begin{array}{l}\text { Radio- } \\
\text { nuclide }\end{array}$} & \multirow{2}{*}{$\begin{array}{c}\text { "Best" } \\
\text { Sediment } K d \mathrm{~s}^{(\mathrm{a})} \\
(\mathrm{mL} / \mathrm{g})\end{array}$} & \multicolumn{4}{|c|}{$\begin{array}{l}\text { CDP Correction Factors Assuming No Enhanced } \\
\text { Sorption in the Presence of DOC }\end{array}$} & \multicolumn{4}{|c|}{ CDP Corrected $K d(\mathrm{~mL} / \mathrm{g})$} \\
\hline & & $\begin{array}{c}10 \\
\mathrm{mg} / \mathrm{L} \mathrm{C}\end{array}$ & $\begin{array}{l}20 \\
\mathrm{mg} / \mathrm{L} \mathrm{C}\end{array}$ & $\begin{array}{l}95 \\
\mathrm{mg} / \mathrm{L} \mathrm{C}\end{array}$ & $\stackrel{222}{\mathrm{mg} \mathrm{L} \mathrm{C}}$ & $\begin{array}{c}10 \\
\mathrm{mg} / \mathrm{L} \mathrm{C}\end{array}$ & $\begin{array}{c}20 \\
\mathrm{mg} / \mathrm{L} \mathrm{C}\end{array}$ & $\begin{array}{l}95 \\
\mathrm{mg} / \mathrm{L} \mathrm{C}\end{array}$ & $\begin{array}{c}222 \\
\mathrm{mg} / \mathrm{L} \mathrm{C}\end{array}$ \\
\hline I-Clay & 0.6 & $1.0^{(\mathrm{b})}$ & $1.0^{(\mathrm{b})}$ & $1.0^{(\mathrm{b})}$ & $1.0^{(\mathrm{b})}$ & 0.6 & 0.6 & 0.6 & 0.6 \\
\hline I - Sand & 0 & $1.0^{(\mathrm{b})}$ & $1.0^{(\mathrm{b})}$ & $1.0^{(\mathrm{b})}$ & $1.0^{(\mathrm{b})}$ & 0 & 0 & 0 & 0 \\
\hline Tc-Clay & 0.1 & $1.0^{(\mathrm{b})}$ & $1.0^{(\mathrm{b})}$ & $1.0^{(\mathrm{b})}$ & $1.0^{(\mathrm{b})}$ & 0.1 & 0.1 & 0.1 & 0.1 \\
\hline Tc - Sand & 0.2 & $1.0^{(\mathrm{b})}$ & $1.0^{(\mathrm{b})}$ & $1.0^{(\mathrm{b})}$ & $1.0^{(\mathrm{b})}$ & 0.2 & 0.2 & 0.2 & 0.2 \\
\hline Se-Clay & 1000 & 1.0 & 1.0 & 1.0 & 0.5 & 1000 & 1000 & 1000 & 500 \\
\hline Se - Sand & 1000 & 1.0 & 1.0 & 0.2 & 0.07 & 1000 & 1000 & 200 & 70 \\
\hline
\end{tabular}

(a) "Best" $K_{d}$ values from Table 10 in Kaplan (2006), which are presently being used for PA/CA calculations.

(b) Essentially no I ( $K d$ values in the presence of CDP ranged from -0.6 to $0.2 \mathrm{~mL} / \mathrm{g}$; Table 4 in Kaplan and Serkiz (2006)) or Tc sorption (Kd values in the presence of CDP ranged from -0.6 to $0.7 \mathrm{~mL} / \mathrm{g}$; Table 4 in Kaplan and Serkiz (2006)) to the sandy or clayey sediment was observed. Therefore it was not possible to determine a correction factor (any value divided by zero is undefined). Values of unity are entered in this table with this caveat. 
SRNL-STI-2012-00138

Revision 0

4.0 Appendix B: Total Organic Carbon Concentrations in the Old Radioactive Waste Burial Ground 
Table 3. Total organic carbon concentrations in wells located within the Old Radioactive Waste Burial Ground. (Data from McIntrye and Wilhite 1987; DPST-87-762). Data used to establish CDP concentrations in the ELLWF.

\begin{tabular}{|c|c|c|c|c|c|c|}
\hline Well ID & $\begin{array}{l}\text { Oct } \\
1982 \\
\end{array}$ & $\begin{array}{l}\text { Mar } \\
1984 \\
\end{array}$ & $\begin{array}{l}\text { Jun } \\
\mathbf{1 9 8 4} \\
\end{array}$ & $\begin{array}{l}\text { Sept } \\
1984\end{array}$ & $\begin{array}{l}\text { Jun } \\
1985 \\
\end{array}$ & From Figure 4 DPST-83-209 \\
\hline & ---- & -------1 & $(\mathrm{mg} / \mathrm{L}$ & -1--- & ------ & \\
\hline A-1 & 3.7 & $0.5^{(\mathrm{a})}$ & 0.5 & & & \\
\hline A-3 & 0 & 3.2 & 0.5 & 0.5 & & \\
\hline A-5 & 0 & 0.5 & 0.5 & & & \\
\hline A-7 & & 0.5 & 0.5 & & & \\
\hline A-9 & & 0.5 & 0.5 & & & \\
\hline A-11 & 0 & 0.5 & 0.5 & & & \\
\hline A-19 & 0 & 0.5 & 0.5 & & & \\
\hline A-21 & 0 & 0.5 & 0.5 & & & \\
\hline A-23 & 5.6 & 1.6 & 1.2 & & & \\
\hline A-32 & 5.2 & 0.5 & 2 & & & \\
\hline A-34 & 0.4 & 0.5 & 0.5 & & & \\
\hline A-36 & 4 & 5.6 & 0.5 & 0.5 & & \\
\hline $\mathrm{C}-1$ & 0 & 1 & & & & \\
\hline $\mathrm{C}-3$ & 0 & 1.8 & 3 & & 38.8 & Potentially impacted by decon. station (p. 7) ${ }^{(b)}$ \\
\hline $\mathrm{C}-5$ & 0 & 0.5 & 2.6 & 25.3 & 11.2 & \\
\hline $\mathrm{C}-7$ & 0 & 3.8 & 3.8 & 11.4 & & \\
\hline C-9 & 6 & 0.5 & 1.3 & 2.2 & & \\
\hline $\mathrm{C}-11$ & 11 & 0.5 & & 0.5 & & \\
\hline $\mathrm{C}-13$ & 0 & 0.5 & 0.5 & & & \\
\hline $\mathrm{C}-15$ & 0 & 5.6 & 0.5 & 0.5 & & Potentially impacted by solvent plume \\
\hline $\mathrm{C}-17$ & 20.9 & 0.5 & 0.5 & & & Potentially impacted by solvent plume \\
\hline $\mathrm{C}-19$ & 0 & 1 & 2.2 & & & \\
\hline $\mathrm{C}-21$ & 18 & 2.8 & 0.5 & 0.5 & & \\
\hline $\mathrm{C}-23$ & 0 & 6.5 & 1.4 & 0.5 & & \\
\hline $\mathrm{C}-30$ & 12.1 & 0.5 & 0.5 & & & \\
\hline $\mathrm{C}-32$ & 0 & 3.7 & 3.9 & & & \\
\hline $\mathrm{C}-34$ & 8 & 1.3 & 1.6 & & & \\
\hline $\mathrm{C}-36$ & 3 & 0.5 & 0.5 & & & \\
\hline E-1 & 10.1 & 2.4 & 1.9 & & & \\
\hline E-3 & 11.9 & 2.4 & 0.5 & 14 & 8.1 & \\
\hline E-5 & 3.9 & 3.5 & 0.5 & 0.5 & & \\
\hline E-7 & 5 & 2.5 & 0.5 & 0.5 & & \\
\hline E-9 & 10 & 3.4 & 2.7 & & & \\
\hline E-13 & 4.3 & 0.5 & 0.5 & & & Potentially impacted by solvent plume \\
\hline
\end{tabular}




\begin{tabular}{|c|c|c|c|c|c|c|}
\hline Well ID & $\begin{array}{l}\text { Oct } \\
1982 \\
\end{array}$ & $\begin{array}{l}\text { Mar } \\
1984\end{array}$ & $\begin{array}{l}\text { Jun } \\
1984 \\
\end{array}$ & $\begin{array}{l}\text { Sept } \\
1984 \\
\end{array}$ & $\begin{array}{l}\text { Jun } \\
\mathbf{1 9 8 5} \\
\end{array}$ & From Figure 4 DPST-83-209 \\
\hline E-15 & & & 2 & 0.5 & 8.1 & \\
\hline E-17 & 0.4 & 0.5 & 6.9 & 0.5 & & Potentially impacted by solvent plume \\
\hline E-19 & 0.2 & 1.5 & 1.2 & & & Potentially impacted by solvent plume \\
\hline E-21 & 10 & 0.5 & 0.5 & & & \\
\hline E-23 & 3.3 & 1.1 & 0.5 & 0.5 & & \\
\hline E-30 & 3 & 0.5 & 0.5 & 0.5 & & \\
\hline E-32 & 0 & 1.5 & 8.5 & 0.5 & & \\
\hline E-34 & 0 & 0.5 & 0.5 & & & \\
\hline E-36 & 25 & 0.5 & 0.5 & & & \\
\hline G-1 & 0 & 2.5 & 0.5 & 0.5 & & \\
\hline G-3 & 0 & 2.1 & 0.5 & 0.5 & & \\
\hline G-5 & 0 & 2.2 & 0.5 & 0.5 & & \\
\hline G-7 & 45 & 61.4 & 65.6 & & 30.3 & \\
\hline G-9 & 9 & 2.9 & 0.5 & 0.5 & & \\
\hline G-13 & 0 & 6.2 & 0.5 & 0.5 & & Potentially impacted by solvent plume \\
\hline G-15 & 0 & 0.5 & 0.5 & & & Potentially impacted by solvent plume \\
\hline G-17 & 0 & 0.5 & 0.5 & & & Potentially impacted by solvent plume \\
\hline G-19 & 4 & 0.5 & 0.5 & & & Potentially impacted by solvent plume \\
\hline G-21 & 225 & 400 & 317 & & 946 & Potentially impacted by solvent plume \\
\hline G-23 & 0 & 0.5 & 0.5 & & & \\
\hline G-28 & 0 & 1.5 & 0.5 & 1 & & \\
\hline G-30 & 4 & 1.8 & 0.5 & 0.5 & & \\
\hline G-32 & 0 & 1.7 & 18 & 11.2 & 14.3 & \\
\hline G-34 & 0 & 0.5 & 0.5 & & & \\
\hline G-36 & 4 & 0.5 & 0.5 & & & \\
\hline $\mathrm{I}-1$ & 16 & 5.4 & 4.2 & & & \\
\hline $\mathrm{I}-3$ & & 5.5 & 2.4 & & & \\
\hline I-5 & 6 & 21.5 & 364 & & 334 & Potentially impacted by solvent plume \\
\hline I-7 & 8 & 30 & 26 & & 64.5 & Potentially impacted by solvent plume \\
\hline $\mathrm{I}-9$ & 3 & 5.4 & 0.5 & 0.5 & & Potentially impacted by solvent plume \\
\hline $\mathrm{I}-13$ & 1 & 0.5 & 0.5 & & & Potentially impacted by solvent plume \\
\hline $\mathrm{I}-15$ & 0 & 0.5 & 0.5 & & & Potentially impacted by solvent plume \\
\hline $\mathrm{I}-17$ & 1.6 & 0.5 & 0.5 & 75.1 & & Potentially impacted by solvent plume \\
\hline AVE & 5.0 & 2.9 & 2.9 & 3.2 & 12.0 & Grand Average $=5.2$ \\
\hline
\end{tabular}




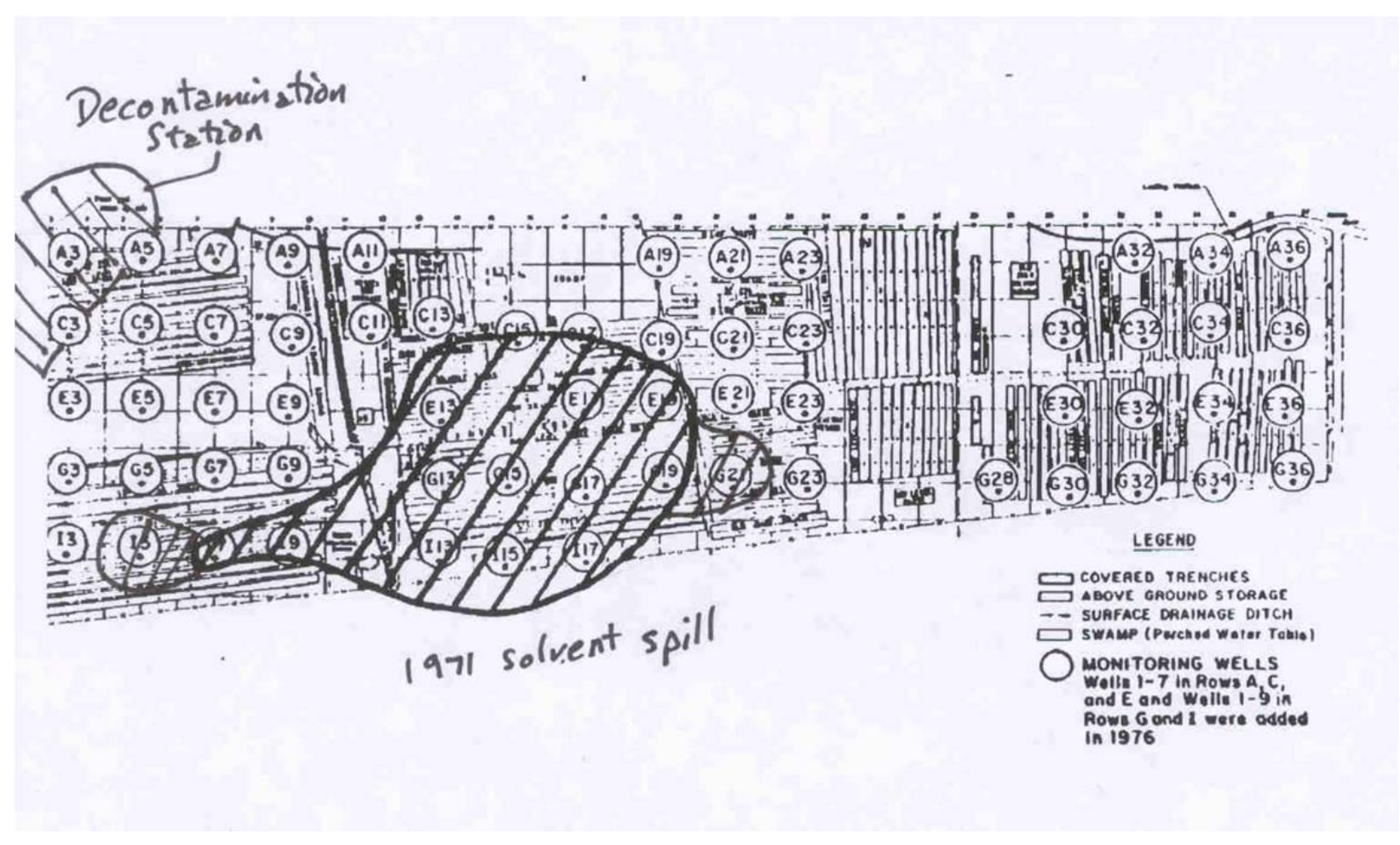

Figure 2. Map of wells used to collect total organic carbon data at Old Radioactive Waste Burial Ground (ORWBG). Outline shows plume from 1971 solvent spill and plume generated near decontamination station. 


\section{Distribution:}

R. S. Aylward, 773-42A - Rm. 281

B. T. Butcher, 773-43A - Rm. 212

L. B. Collard, 773-43A - Rm.207

D. A. Crowley, 773-43A - Rm.216

G. P. Flach, 773-42A - Rm. 211

R. A. Hiergesell, 773-43A - Rm.218

J. J. Mayer, 773-42A, - Rm. 242

D. Li , 999-W - Rm. 216

D. I. Kaplan, 773-43A - Rm.215

K. A. Roberts, 773-43A - Rm.225

F. G. Smith, III 773-42A - Rm.178

G. A. Taylor, 773-43A - Rm.230

WPT File ( 2 copies) - 773-43A, Rm. 213 